\title{
Analisa Penggunaan Perangkat Lunak dalam Mendukung Pembukuan Keuangan Sekolah
}

\author{
Rafiq Ahmad ${ }^{1}$, Agustine Dwianika ${ }^{2}$ \\ ${ }^{1,2}$ Program Studi Akuntansi \\ ${ }^{1,2}$ Universitas Pembangunan Jaya, Tangerang Selatan, Banten \\ Email : rafiq.ahmad@student.upj.ac.id ${ }^{1}$, agustine.dwianika@upj.ac.id ${ }^{2}$
}

\begin{abstract}
ABSTRAK
Pembukuan dibuat agar setiap transaksi keuangan tercatat dengan baik. Penyusunan pembukuan keuangan sekolah secara konvensional atau manual, seringkali mengalami kendala, seperti kesalahan pencatatan dan perhitungan. Perkembangan tekonologi informasi dan komunikasi, menghasilkan produk digital seperti perangkat lunak untuk menjawab setiap permasalahan. Pengunaan perangkat lunak dapat menyusun pembukuan dengan mudah dan cepat. Tujuan penelitian ini, untuk menganalisa penggunaan perangkat lunak asisten dalam mendukung pembukuan keuangan di sekolah Fadilah (taman kanak-kanak, sekolah dasar, dan sekolah menengah kejuruan). Data diperoleh dengan cara observasi, dan wawancara kepada responden menggunakan teknik purposive sampling dengan memilih kriteria tertentu yaitu, kepala tata usaha, bendahara, dan staf tata usaha sekolah Fadilah. Teknik analisis data penelitian ini menggunakan teknik analisis deskriftif. Penelitian ini memperoleh hasil bahwa perangkat lunak asisten dapat membantu pembukuan sekolah, dikarenakan memiliki efektifitas dan efesiensi dalam penggunaanya.
\end{abstract}

Kata Kunci : Pembukuan, Perangkat lunak asisten, Sekolah Fadilah.

\section{ABSTRACT}

Bookkeeping made so that every financial transaction recorded properly. Conventional or manual bookkeeping of school is often experiences problem, such as recording and calculation errors. The development of information and communication technology, has resulted in digital product such as software to answer every problem. The use of software can compile bookkeeping easily and quickly. The purpose of this study, to analyze the use of asisten software in supporting the bookkepping at Fadilah School (kindergarten, primary school, and vocational highschool). Data obtained by observation, and interviews to respondents using purposive sampling technique with certain criteria that is head of administrasion, treasurer, and administrative staff of the Fadilah School. The data analysis technique used in this research was descriptive analysis technique. This study obtained the results that the asisten software can help bookkeeping of school, because it has effectiveness and efficiency in its use.

Keywords : Bookkeeping, Asisten software, Fadilah school. 


\section{PENDAHULUAN}

Pendidikan adalah pengajaran yang diselenggarakan di sekolah sebagai lembaga pendidikan formal (Machali \& Hidayat, 2016). Lembaga Pendidikan dari semua jenjang pendidikan, memerlukan pemasukan (uang) untuk membiayai segala pembiayaan pendidikan untuk menunjang operasional sekolah. Biaya pendidikan adalah sumber daya yang dikeluarkan oleh pemerintah, masyarakat, maupun orang tua siswa kepada sekolah baik dalam bentuk barang maupun uang yang dikumpulkan dan ditetapkan untuk mencapai tujuan Pendidikan (Tagotorop, 2017). Pembiayaan pendidikan penting agar tujuan sekolah dapat tercapai dengan baik. Standar pembiayaan pendidikan terdiri atas biaya investasi, biaya operasi, dan biaya personal. Biaya investasi satuan pendidikan meliputi biaya penyediaan sarana dan prasarana, pengembangan sumber daya manusia, dan modal kerja tetap. Sedangkan, biaya personal meliputi biaya pendidikan yang harus dikeluarkan oleh peserta didik untuk bisa mengikuti proses pembelajaran secara teratur dan berkelanjutan. Biaya operasi satuan pendidikan sebagaimana dimaksud meliputi, gaji pendidik dan tenaga kependidikan serta segala tunjangan yang melekat pada gaji, bahan atau peralatan pendidikan habis pakai, dan biaya operasi pendidikan tak langsung berupa daya, air, jasa telekomunikasi, pemeliharaan sarana dan prasarana, uang lembur, transportasi, konsumsi, pajak, asuransi, dan lain sebagainya (Kusumadewi, 2015). Pembiayaan pendidikan perlu dikelola dengan baik agar setiap dana dapat digunakan untuk meningkatkan mutu sekolah sehingga mampu bersaing dengan sekolah lainnya.

Pembiayaan pendidikan memerlukan pengelolaan keuangan yang baik agar setiap pembiayaan yang dikeluarkan dapat tercatat. Oleh karena itu, perlu untuk melakukan pembukuan pada lembaga pendidikan. Pembukuan (bookkeeping) adalah pencatatan data transaksi perusahaan menurut cara tertentu dan merupakan bagian dari akuntansi (Ardhianto, 2019). Dengan adanya pembukuan suatu perusahaan atau organisasi dapat memberikan gambaran yang jelas terkait transaksi keuangan yang dilakukan. Sehingga, dapat menjadi bahan acuan untuk pengambilan keputusan, agar keberlangsungan hidup perusahaan atau organisasi dapat berjalan dengan baik.

Pembukuan dalam kegiatan pengurusan keuangan pendidikan meliputi dua hal, yaitu pertama pengurusan yang menyangkut kewenangan menentukan kebijakan menerima atau 
mengeluarkan uang. Pengurusan ini dikenal dengan istilah pengurusan ketatausahaan. Pengurusan kedua menyangkut tindak lanjut dari urusan pertama yakni, menerima, menyimpan dan mengeluarkan uang. Pengurusan ini tidak menyangkut kewenangan menentukan, tetapi hanya melaksanakan, dan dikenal dengan istilah pengurusan bendaharawan (Arwildayanto, Lamatenggo, \& Sumar, 2017). Bendaharawan sekolah memiliki tugas utama yaitu melaksanakan seluruh administrasi keuangan sekolah dan bertanggung jawab kepada Kepala Tata Usaha.

Perkembangan teknologi informasi dan komunikasi sangat bermanfaat dalam mengatasi permasalahan-permasalahan yang terjadi, dan dapat membantu setiap pekerjaan agar lebih mudah dan cepat. Produk digital merupakan hasil dari perkembangan tekonologi informasi dan komunikasi. Salah satu produk digital yang sering digunakan oleh banyak orang, yaitu perangkat lunak atau sering disebut software. Menurut (Utami \& Asnawati, 2015) software adalah perangkat lunak yang berisikan sebuah intruksi yang diperintahkan dan diproses dengan bantuan perangkat keras sehingga tanpa perangkat perangkat lunak maka perangkat keras tidak bisa dipakai sehingga software dan hardware tidak bisa dipisahkan. Oleh karena itu, perangkat lunak sangat bermanfaat untuk menunjang setiap perkerjaan yang terkomputerisasi. Berbagai macam perangkat lunak dibuat untuk membantu pekerjaan manusia di segala macam aspek, salah satunya perangkat lunak yang dibuat khusus untuk pembukuan sekolah. Dalam proses pembukuan keuangan sekolah dengan menggunakan metode konvensional atau manual, seringkali mengalami berbagai macam kendala seperti kesalahan dalam pencatatan dan perhitungan, dikarenakan banyaknya proses transaksi yang ada, serta sulit untuk membuat laporan keuangan dengan cepat. Penggunaan perangkat lunak untuk melakukan pembukuan merupakan solusi yang tepat, untuk menyelesaikan permasalahan tersebut.

Sekolah Fadilah merupakan lembaga pendidikan yang menaungi beberapa jenjang Pendidikan sekolah mulai dari TK (Taman Kanak-Kanak), SD (Sekolah Dasar), dan SMK (Sekolah Menengah Kejuruan) Fadilah. Sekolah Fadilah melakukan pembukuan maupun administrasi keuangan sekolah, dengan menerapkan metode konvensional atau manual, sehingga mengalami berbagai macam kendala seperti kesalahan dalam pencatatan dan perhitungan dikarenakan banyaknya proses transaksi yang ada, dan sulit untuk membuat 
laporan keuangan dengan cepat. Maka dari itu, Sekolah Fadilah menggunakan perangkat lunak untuk pembukuan, yaitu asisten.

Asisten adalah perangkat lunak yang dirancang khusus untuk membantu dalam proses pembukuan keuangan sekolah dan pengelolaan administrasi keuangan. Sekolah Fadilah sudah menggunakan asisten sejak tahun 2014. Asisten membantu berbagai macam kebutuhan sekolah seperti pembukuan, administrasi keuangan, dan lainnya secara terkomputerisasi. Software asisten memberikan kemudahan dalam proses input dan rekapitulasi data, selain itu data yang tersimpan berbasis database yang terkomputerisasi sehingga akses pencarian informasi keuangan sekolah yang sudah tersimpan menjadi lebih mudah dan bersifat informatif (Bukhori dkk, 2020).

Penelitian ini dilakukan berdasarkan pada penelitian sebelumnya yang dibuat oleh Bukhori,dkk dengan judul penelitian yaitu, "Pendayagunaan Software Asisten Dalam Pengelolaan Sistem Informasi Manajemen Keuangan Sekolah”. Hasil penelitian tersebut yaitu pendayagunaan software atau perangkat lunak keuangan terkomputerisasai layak digunakan sebagai perangkat lunak adminitrasi keuangan sekolah. Dengan adanya software asisten, pengelolaan keuangan yang didalamnya terdapat pengelolaan pembiayaan sekolah akan menunjang terselenggaranya proses pembelajaran yang efektif dan mendukung tercapainya tujuan sekolah (Bukhori dkk, 2020). Berdasarkan penjelasan di atas, menjadi perhatian penulis untuk melakukan penelitian lebih lanjut, yang bertujuan untuk menganalisa mengenai penggunaan perangkat lunak asisten dalam mendukung pembukuan keuangan sekolah di Sekolah Fadilah (Taman Kanak-kanak, Sekolah Dasar, dan Sekolah Menengah Kejuruan Fadilah).

\section{METODE PENELITIAN}

Metode penelitian yang dilakukan dalam penelitian ini menggunakan pendekatan kualitatif. Penelitian kualitatif adalah satu kegiatan sistematis untuk melakukan eksplorasi atas teori dari fakta di dunia nyata, bukan untuk menguji teori atau hipotesis. (Rukajat, 2018). Teknik pengumpulan data dalam penelitian ini melalui wawancara dan observasi dengan mengajukan pertanyaan kepada responden untuk mendapatkan informasi dan gambaran mengenai permasalahan yang diteliti. Dalam penelitian ini, sumber data yang 
diperoleh berasal dari responden/partisipan menggunakan teknik purposive sampling, dengan memilih kriteria tertentu yaitu responden yang menggunakan perangkat lunak asisten dalam melakukan pekerjaannya di sekolah Fadilah. Adapun responden tersebut yaitu, Kepala Tata Usaha, Bendahara, dan Staf Tata Usaha sekolah fadilah. Teknik analisis data yang digunakan pada penelitian ini menggunakan teknik analisis deskriftif. Lokasi penelitian yang dilakukan penulis, yaitu pada Sekolah Fadilah. Sekolah Fadilah merupakan lembaga pendidikan, penggunaan perangkat lunak asisten menjadi hal utama dalam membantu proses administrasi sekolah, mulai dari pendataan siswa, pembukuan, mencetak kartu bayaran siswa, menagih tunggakan pembayaran siswa, serta mengelola keuangan sekolah baik pemasukan dan pengeluaran tercatat dengan rapih menggunakan perangkat lunak tersebut. Sekolah Fadilah mempunyai beberapa sekolah dari berbagai tingkatan mulai dari TK (Taman Kanak-Kanak), SD (Sekolah Dasar), dan SMK (Sekolah Menegah Kejuruan). Tiga sekolah tersebut yang menjadi pusat perhatian penulis untuk meneliti lebih dalam mengenai penggunaan perangkat lunak asisten untuk pembukuan keuangan sekolah.

\section{HASIL DAN PEMBAHASAN}

Berdasarkan hasil wawancara dan observasi yang telah dilakukan di Sekolah Fadilah (TK, SD, dan SMK). Sekolah Fadilah menggunakan perangkat lunak asisten yang saling terhubung antar sekolah (TK, SD, dan SMK), sehingga dapat memudahkan pemantauan atas aktivitas pembukuan yang dilakukan.

\subsection{Flowchart Penerimaan dan Pengeluaran Kas}

Flowchart merupakan bagan yang menunjukkan arus pekerjaan secara keseluruhan dari sistem. Flowchart menjelaskan tentang urutan-urutan dari prosedur yang ada di dalam sistem dengan menggunakan simbol-simbol (Amborowati \& Marco, 2016). Flowchart atas aktivitas penerimaan kas sekolah dan perngeluaran sekolah menjadi hal yang penting, pada flowchart terdapat rangkaian prosedur mengenai langkah-langkah yang harus dijalankan. Adapun flowchart atas aktivitas penerimaan kas atau pendapatan sekolah : 


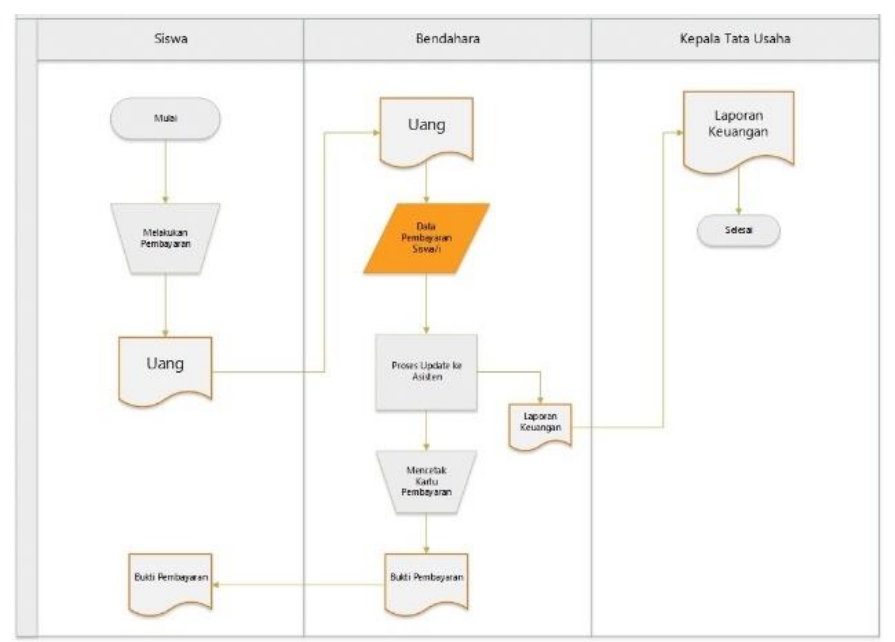

Gambar 1: Flowchart penerimaan kas

Penerimaan kas pada Sekolah Fadilah, berasal dari pembayaran iuran siswa/i. Adapun pembayaran yang dilakukan berupa :

a. SPP (Sumbangan Pembinaan Pendidikan)

Sumbangan Pembinaan Pendidikan dibayar oleh setiap siswa/i setiap bulannya. Pembayaran SPP bertujuan untuk membiayai keperluan pembiayaan pendidikan sehingga kegiatan belajar dapat berjalan dengan baik.

b. EKSKUL (Ekstrakurikuler)

Siswa/i membayar biaya ekskul sekolah selama satu tahun. Pembayaran ekskul bertujuan untuk membiayai pengajar untuk setiap bidang ekskul yang diikuti oleh siswa/i.

c. OSIS (Organisasi Siswa Intra Sekolah)

Siswa/i membayar biaya osis untuk setiap kegiatan yang dibuat atau dilaksanakan oleh osis, biaya ini dibayar selama satu tahun.

d. Ujian Semester

Biaya ujian semester wajib dibayar oleh siswa/i untuk mengikuti ujian, baik ujian tengah semester maupun ujian kenaikan kelas.

e. Ujian Nasional

Biaya ujian nasional dibayar oleh siswa/i untuk mengikuti ujian nasional yang diperuntukan bagi siswa/i tingkat atas sebagai salah satu syarat kelulusan. 


\section{f. Daftar Ulang}

Biaya daftar ulang dibayar oleh siswa/i ketika kenaikan kelas. Biaya ini diperuntukan untuk biaya perawatan gedung dan fasilitas sekolah.

g. Formulir

Biaya formulir dibayar oleh setiap calon siswa/i sebagai syarat pendaftaran masuk ke sekolah.

h. Uang Pangkal

Biaya uang pangkal dikeluarkan ketika calon siswa/i masuk ke sekolah tersebut, dan hanya dikenakan satu kali. Uang pangkal digunakan untuk dana pembangunan sekolah.

i. Biaya Seragam

Biaya seragam dikenakan bagi calon siswa/i untuk membeli seragam khusus untuk pakaian sekolah sehari-hari.

j. Biaya Kegiatan

Biaya yang dikeluarkan oleh siswa/i yang sifatnya tidak wajib untuk berbagai macam kegiatan sekolah seperti biaya study tour dan field trip.

Biaya-biaya tersebut, menjadi penerimaan kas atau pendapatan sekolah untuk pembiayaan pendidikan sekolah. Berdasarkan flowchart penerimaan kas sekolah, berasal dari pembayaran siswa untuk membayar biaya tersebut dengan memberikan nominal uang tertentu kepada bendahara. Selanjutnya, bendahara menginput data atas pembayaran siswa ke asisten, lalu asisten memperbarui data dan menyimpannya ke database. Bendahara mencetak kartu sebagai bukti pembayaran, lalu memberikannya kepada siswa. Bendahara juga membuat laporan keuangan, dan diberikan kepada kepala tata usaha setiap akhir bulan.

Pengeluaran kas yang dilakukan oleh Sekolah Fadilah, digunakan untuk membiayai pembiayaan pendidikan seperti biaya gaji karyawan untuk setiap bulannya, ATK (Alat Tulis Kantor), listrik, telepon, air, internet, kegiatan sekolah, fasilitas gedung sekolah dan pengeluaran yang bersifat umum lainnya. Proses pengeluaran kas tersebut tentu harus melewati beberapa tahapan, sehingga setiap proses transaksi pengeluaran kas dapat dicatat dan disimpan kedalam database hingga data tersebut menjadi laporan keuangan yang akurat 
dan dapat dipertanggungjawabkan. Berikut gambar flowchart pengeluaran kas sekolah Fadilah :

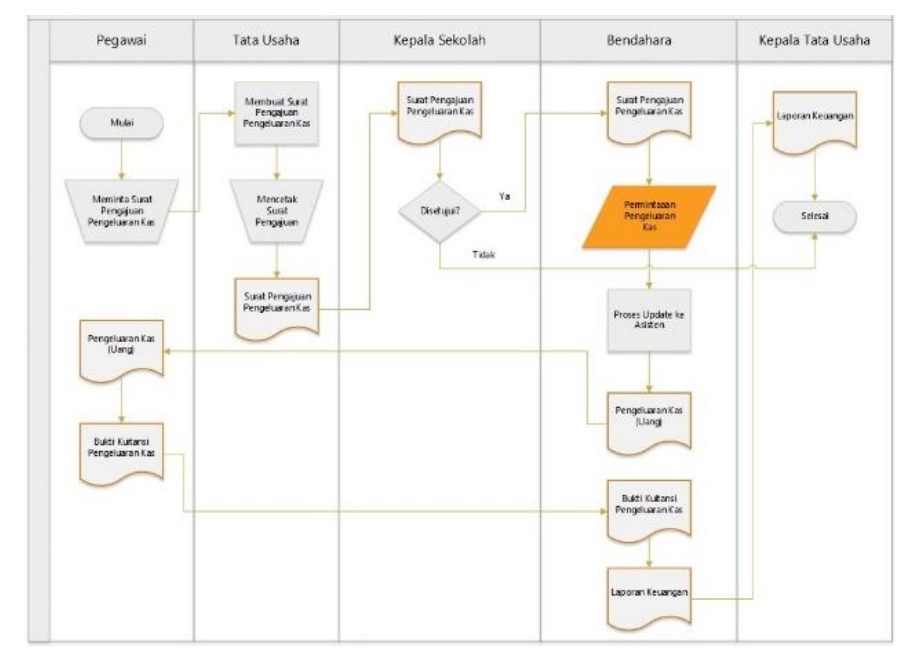

Gambar 2: Flowchart pengeluaran kas

Pada flowchart aktivitas pengeluaran kas, pegawai mengajukan pembuatan surat pengajuan pengeluaran kas kepada petugas tata usaha, lalu petugas tata usaha membuatkan surat dan mencetak surat tersebut, kemudian surat pengajuan pengeluaran kas diajukan kepada kepala sekolah. Kepala sekolah menindaklanjuti atas surat pengajuan tersebut, jika disetujui kepala sekolah memberikan surat persetujuan kepada bendahara. Bendahara menginput data permintaan pengeluaran kas pada asisten berdasarkan pos pengeluaran, kemudian asisten memperbarui data dan disimpan ke database. Kemudian, bendahara memberikan uang kepada pegawai, lalu pegawai menggunakan uang tersebut dengan memberikan bukti kuitansi pengeluaran kas kepada bendahara. Bendahara menerima bukti tersebut, dan membuat laporan keuangan yang akan diberikan kepada kepala tata usaha setiap akhir bulan.

\subsection{Penggunaan Asisten untuk Pembukuan Keuangan Sekolah}

Asisten merupakan perangkat lunak khusus pembukuan sekolah yang telah digunakan oleh Sekolah Fadilah sejak tahun 2014. Asisten membantu segala proses administrasi kesiswaan seperti mencetak kartu ulangan dan menginput data siswa/i secara lengkap sesuai dengan kelas, serta memudahkan dalam mengelola keuangan sekolah. Asisten 
memudahkan untuk pembayaran siswa/i dimana dengan menggunakan asisten terlihat data siswa/i yang menunggak pembayaran sekolah, serta dapat memberikan informasi tunggakan kepada seluruh siswa/i. Berikut tampilan gambar asisten :

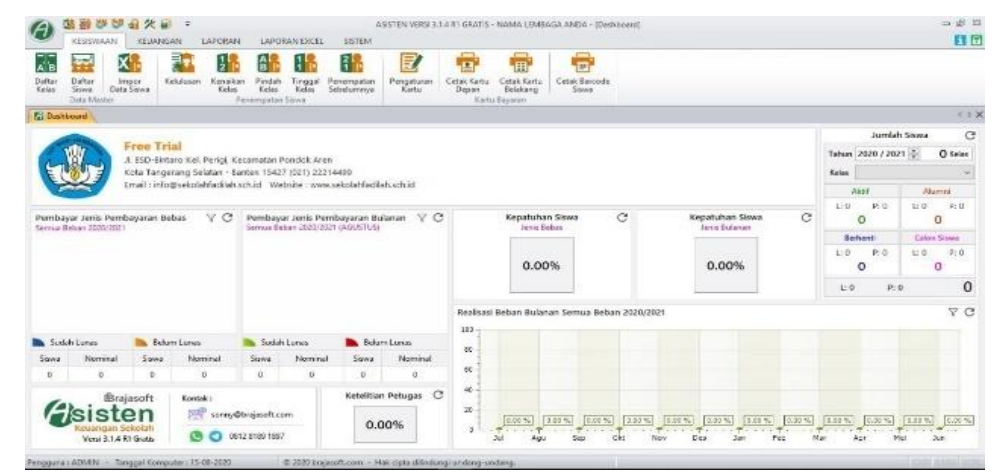

Gambar 3: Dashboard asisten versi free trial

Tampilan dashboard asisten menggambarkan keseluruhan data keuangan sekolah yang digambarkan dalam bentuk grafik dan persentase. Data tersebut menunjukan pembayaran siswa/i yang dapat ditampilkan baik bulanan hingga tahunan. Sehingga, dapat dijadikan bahan acuan untuk dapat terus meningkatkan kepatuhan siswa/i untuk membayar kewajibannya.

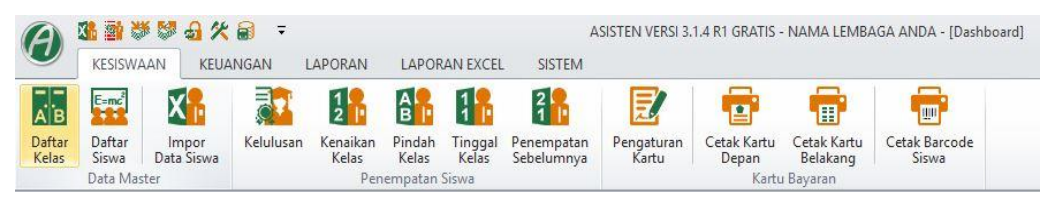

Gambar 4: Menu kesiswaan

Menu kesiswaan digunakan untuk mengisi atau menginput data siswa/i berdasarkan kelas, lalu pada menu ini juga dapat digunakan untuk cetak kartu ujian dan kode barcode yang nantinya ditempelkan atau dicetak di kartu bayaran siswa/i.

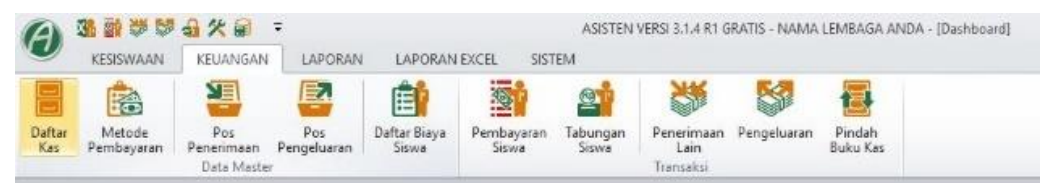

Gambar 5: Menu keuangan

Menu keuangan merupakan menu yang sangat penting dalam proses pembukuan. Pada menu keuangan terdapat pembayaran siswa, penerimaan lain (kas), dan pengeluaran 
yang dimana bendahara sering menggunakan menu tersebut untuk proses pembukuan. Pada proses penerimaan kas, bendahara menginput data pembayaran siswa, dan asisten secara otomatis memperbarui data keuangan tersebut kedalam sistem database. Kemudian, jika terdapat penerimaan lain yang bukan berasal dari siswa seperti dana bos, dan donatur, maka menggunakan pilihan penerimaan lain. Proses pengeluaran kas dengan menggunakan pilihan pengeluaran yang dimana data keuangan untuk pengeluaran akan tercatat dan tersimpan kedalam sistem database pada perangkat lunak asisten.

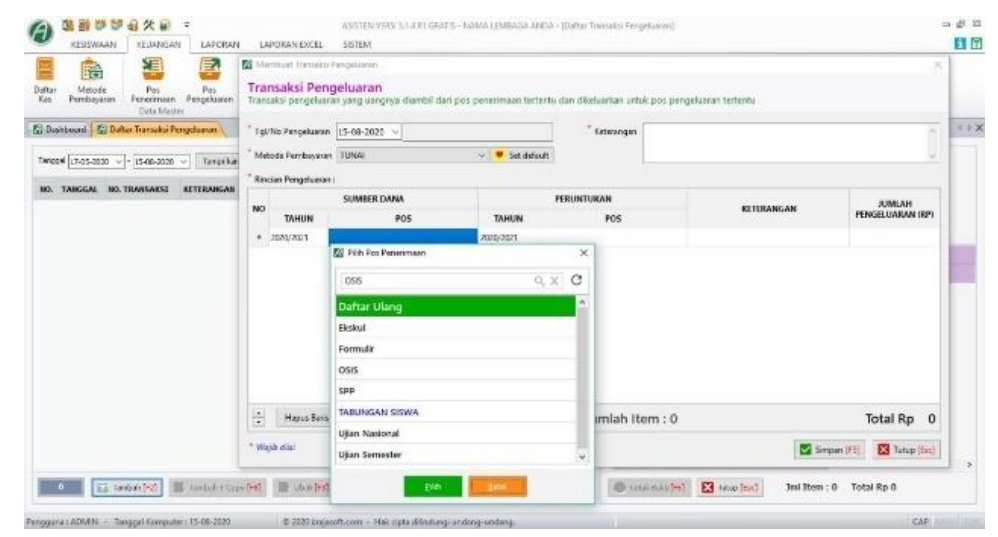

Gambar 6: Transaksi pengeluaran

Pada transaksi pengeluaran, uang kas yang dikeluarkan menggunakan pos penerimaan kas yang berasal dari pembayaran siswa/i, seperti pembayaran SPP, OSIS, EKSKUL, dan yang lainnya. Sehingga, pengurangan atas penerimaan kas dan penambahan atas pengeluaran kas dapat tercatat dan tersimpan secara sistematis.

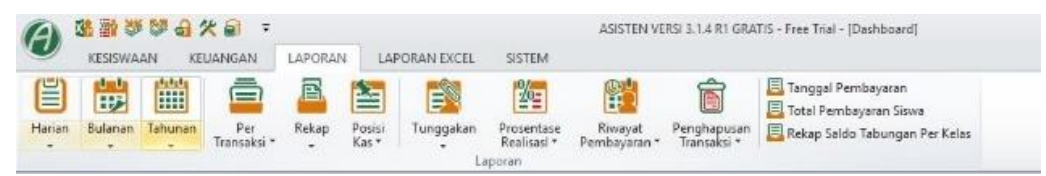

Gambar 7: Menu laporan

Pada menu laporan, laporan keuangan atas transaksi pengeluaran dan penerimaan kas dapat dibuat laporan secara harian, bulanan, maupun tahunan. Serta, dapat merekap setiap jenis transaksi. Lalu, terdapat laporan mengenai data tunggakan serta realisasi presentasi siswa/i yang membayar secara keseluruhan, hal ini berguna untuk pengambilan keputusan untuk meningkatkan kesadaran siswa/i membayar kewajibannya. 


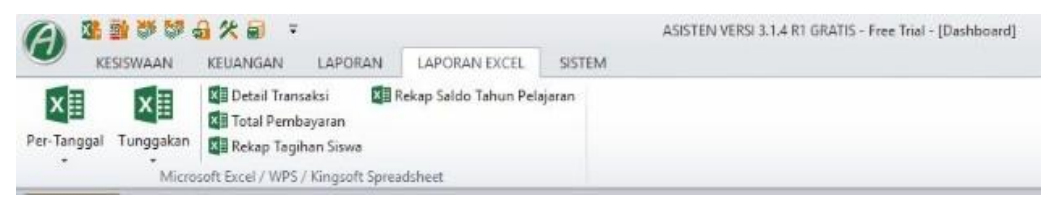

Gambar 8: Menu Laporan Excel

Sesuai dengan nama menunya, menu laporan excel digunakan untuk mengekspor data keuangan dari asisten kedalam file excel.

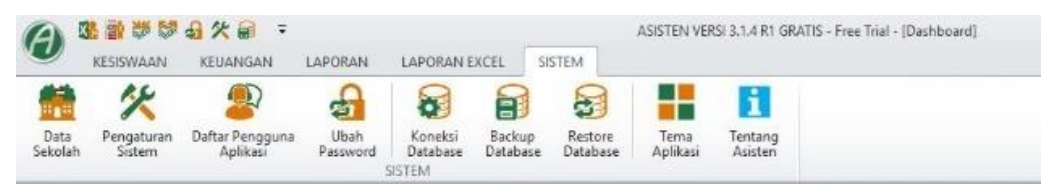

Gambar 9: Menu Sistem

Pada menu sistem, digunakan untuk melakukan pengaturan sistem, serta dapat mengubah password pengguna agar lebih aman dan terlindungi serta dapat mengatur sistem database asisten.

\subsection{Hasil Wawancara dengan Responden}

Berdasarkan hasil wawancara dengan responden dengan memberikan kuesioner, diperoleh lima responden, sebagai berikut :

Tabel 1. Profil responden

\begin{tabular}{clcc}
\hline No. & \multicolumn{1}{c}{ Nama } & Jabatan & $\begin{array}{c}\text { Jenjang } \\
\text { Pendidikan }\end{array}$ \\
\hline 1. & Andri Wijaya, S.Kom. & Kepala Tata Usaha & S1 \\
\hline 2. & Nurul Lia & Bendahara & SMA/K \\
\hline 3. & Sartini Murni & Staf Tata Usaha & SMA/K \\
\hline 4. & Nadia Amalia & Staf Tata Usaha & SMA/K \\
\hline 5. & Dede Sulaeman, S.Pd. & Staf Tata Usaha & S1 \\
\hline
\end{tabular}

Pertanyaan yang diajukan, terkait dengan penggunaan perangkat lunak asisten dalam mendukung pembukuan keuangan sekolah. Responden telah menggunakan perangkat lunak asisten selama kurang lebih 5 tahun di Sekolah Fadilah (TK, SD, dan SMK). Hasilnya diperoleh bahwa asisten dapat memudahkan penginputan data siswa secara singkat dan 
mudah, sehingga data tersebut dapat digunakan untuk segala jenis transaksi pembayaran siswa. Setiap transaksi pengeluaran sekolah untuk segala pembiayaan pendidikan harus melalui asisten agar setiap transaksi baik pemasukan maupun pengeluaran dapat tercatat dengan baik, sehingga pembukuan dapat dibuat secara cepat dan sistematis. Asisten memudahkan untuk mencari data tunggakan seluruh siswa, staf dapat memberikan informasi kepada siswa dengan cepat mengenai tunggakan pembayaran. Asisten juga dapat membantu merekap data keuangan setiap jenis transaksi. Dengan demikian, responden merasa puas menggunakan perangkat lunak asisten untuk menunjang pekerjaannya, terkait pembukuan keuangan sekolah, karena asisten dapat memberikan efektifitas dan efesiensi.

\section{SIMPULAN}

Sekolah Fadilah (TK, SD, dan SMK) telah mempercayakan perangkat lunak asisten untuk membantu pembukuan sekolah, dikarenakan memiliki efektifitas dan efesiensi dalam penggunaanya. Laporan serta rekapan setiap jenis transaksi baik penerimaan kas maupun pengeluaran kas dapat dibuat dengan cepat, akurat dan dapat dipertanggunggjawabkan. Berbagai menu yang dibuat oleh perangkat lunak asisten bertujuan untuk memudahkan pengguna dalam melakukan pekerjaannya seperti memudahkan pengguna untuk mengetahui jumlah tunggakan siswa, memudahkan untuk merekap data keuangan sekolah, dan memudahkan untuk membuat pembukuan sekolah. Sehingga, penggunaan perangkat lunak asisten dalam mendukung pembukuan keuangan sekolah, memberikan hasil yang baik dan layak untuk digunakan.

\section{DAFTAR PUSTAKA}

Amborowati, A., \& Marco, R. (2016). Analisis Pengelolaan Dan Monitoring Dana Bantuan Operasional Sekolah (Bos) Menggunakan Sistem Informasi Berbasis Website Pada Sltp Di Daerah Istimewa Yogyakarta. Dasi (Data Manajemen Dan Teknologi Informasi), 10.

Ardhianto, W. N. (2019). Buku Sakti Pengantar Akuntansi. Yogyakarta: Quadrant.

Arwildayanto, Lamatenggo, N., \& Sumar, W. T. (2017). Manajemen Keuangan dan Pembiayaan Pendidikan. Bandung: Widya Padjajaran. 
Asifa, P., \& Afriansyah, H. (2020). Administrasi Ketatausahaan Sekolah. OSFPREPRINTS, 3.

Bukhori, I., Rojab, I. S., Sopwandin, I., \& Hidayat, A. (2020). Pendayagunaan Software Asisten Dalam Pengelolaan Sistem Informasi Manajemen Keuangan Sekolah. TADBIR MUWAHHID, 19.

Imron, M. J. (2016). Manajemen Pembiayaan Sekolah. Al-Ibrah, 87.

Kusumadewi, R. F. (2015). Pembiayaan Pendidikan di Indonesia. Jurnal Ilmah Pendidikan Dasar, 47.

Machali, I., \& Hidayat, A. (2016). Teori dan Praktik Pengelolaan Sekolah/Madrasah di Indonesia. Jakarta: KENCANA.

Ma'rifati, I. S. (2015). Sistem Informasi Akuntansi Pendapatan Sumbangan Pembinaan Pendidikan (SPP) Pada SMU XYZ. EVOLUSI: Jurnal Sains dan Manajemen, 2.

Rukajat, A. (2018). Pendekatan Penelitian Kualitatif. Yogyakarta: Deepublish.

Tagotorop, M. (2017). Pengaruh Biaya Pendidikan Terhadap Mutu Sekolah SMA Swasta. SCHOLARIA: Jurnal Pendidikan dan Kebudayaan, 236.

Utami, F. H., \& Asnawati. (2015). Rekayasa Perangkat Lunak. Yogyakarta: Deepublish. 